THE S. MARK TAPER FOUNDATION IMPRINT IN JEWISH STUDIES

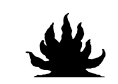

BY THIS ENDOWMENT

THE S. MARK TAPER FOUNDATION SUPPORTS THE APPRECIATION AND UNDERSTANDING OF THE RICHNESS AND DIVERSITY OF JEWISH LIFE AND CULTURE 
The publisher gratefully acknowledges the generous support of the Jewish Studies Endowment Fund of the University of California Press Foundation, which was established by a major gift from the S. Mark Taper Foundation. 
Migrating Tales 


\section{Migrating Tales}

THE TALMUD'S NARRATIVES AND

THEIR HISTORICAL CONTEXT

Richard Kalmin

甲

U NIVERSITY OF CALIFOR IA PRESS 
University of California Press, one of the most distinguished university presses in the United States, enriches lives around the world by advancing scholarship in the humanities, social sciences, and natural sciences. Its activities are supported by the UC Press Foundation and by philanthropic contributions from individuals and institutions. For more information, visit www.ucpress.edu.

University of California Press

Oakland, California

(C) 2014 by The Regents of the University of California

Library of Congress Cataloging-in-Publication Data

Kalmin, Richard Lee.

Migrating tales : the Talmud's narratives and their historical context / Richard Kalmin.

pages $\mathrm{cm}$.

Includes bibliographical references and index.

ISBN 978-0-520-27725-0 (cloth : alk. paper)

ISBN 978-0-520-95899-9 (ebook)

I. Talmud-Criticism, Narrative. 2. Narration in rabbinical

literature. I. Title.

BM509. $\mathrm{N}_{37} \mathrm{~K}_{35} \quad 2014$

$296 . I^{\prime} 2067-\mathrm{dc} 23$

2014002050

Manufactured in the United States of America

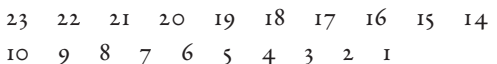

In keeping with a commitment to support environmentally responsible and sustainable printing practices, UC Press has printed this book on Natures Natural, a fiber that contains $30 \%$ post-consumer waste and meets the minimum requirements of ANSI/NISO Z39.48-1992 (R 1997) (Permanence of Paper). 
For Les Lenoff, Richard Sacks, and Claudia Setzer In Friendship 